\title{
Changes in prevalence and intensity of infection of Profilicollis altmani (Perry, 1942) cystacanth (Acanthocephala) parasitizing the mole crab Emerita analoga (Stimpson, 1857): an El Niño cascade effect?
}

\author{
Marcelo E. Oliva · Irene Barrios · Sven Thatje · \\ Jürgen Laudien
}

Received: 14 February 2007/Revised: 22 April 2007/ Accepted: 24 April 2007/Published online: 22 September 2007

(C) Springer-Verlag and AWI 2007

\begin{abstract}
Prevalence and intensity changes in cystacanths of the acanthocephalan Profilicollis altmani parasitizing the mole crab Emerita analoga under El Niño (EN) and non-El Niño (non-EN) conditions are analyzed. Both, mean intensity and prevalence of infection by $P$. altmani differ significantly for the whole size range and for each size class of $10 \mathrm{~mm}$ intervals (except prevalence for size classes exceeding $18 \mathrm{~mm}$ carapace length) between EN (1998) and non-EN (2002) years, without observed size distribution differences in the intermediate host $E$. analoga under either condition. Significant difference in infestation rates of the intermediate host E. analoga is discussed as being an EN cascade effect on predators such as sea birds (i.e., Larus spp. and Calidris sp.), acting as definitive hosts of $P$. altmani, and which are known to decrease significantly in abundance during EN.
\end{abstract}

Communicated by S. Thatje.

Special issue: Climate variability and El Niño Southern Oscillation: implications for natural coastal resources and management.

M. E. Oliva ( () ) I. Barrios

Instituto Investigaciones Oceanológicas,

Universidad de Antofagasta, P.O. Box 170,

Antofagasta, Chile

e-mail: meoliva@uantof.cl

S. Thatje

National Oceanography Centre, Southampton,

School of Ocean and Earth Science,

University of Southampton, European Way,

Southampton SO14 3ZH, UK

J. Laudien

Alfred Wegener Institute for Polar and Marine Research,

Am Alten Hafen 26, 27568 Bremerhaven, Germany
Keywords ENSO - Crustacean · Parasites · Humboldt Current System

\section{Introduction}

As emphasized by Arntz (2002), changes undergone by marine ecosystems during strong El Niño (EN) can be used as a proxy of how these systems may have responded to past climate variability and how they will respond to future changes. Such large-scale climatic fluctuations are known to affect a multitude of ecological processes (Arntz 2002; Fiedler 2002). Climate oscillation, and thus changes in ambient temperature, affects several ecological and physiological processes. This ranges from the performance of individual organisms to the dynamics of populations, including the distribution of species, changes in species dominance and diversity, reproductive biology, population dynamics, and behavior (Arntz 2002; Poulin 2006; Poulin and Mouritsen 2006; Arntz et al. 2006).

Parasites occur in almost every population (Lafferty and Kuris 1999) and parasitism is regarded as one of the most successful ways of life, considering that more than $50 \%$ of all living forms are parasites (Windsor 1998). However, despite the strong evidence that parasites can influence the composition and structure of natural communities (Minchella and Scott 1991; Hudson and Greenman 1998) and that parasite transmission is often strongly affected by weather conditions (Mouritsen and Poulin 2002), there are few papers dealing with parasites and changes induced by natural oceanographic phenomena such as El Niño-Southern Oscillation (ENSO).

The mole crab Emerita analoga (Anomura: Hippidae) is dominating soft-bottom intertidal and upper sub-tidal 
communities along the Pacific coast off South America (Osorio and Bahamonde 1967) and is of great importance in the food web (Koepcke and Koepcke 1952), i.e., being an important prey for fish (both teleost and elasmobranchs) and birds (Larus spp. and Calidris sp.). Alvitres et al. (2002) and Contreras et al. (2000) indicated that E. analoga lives up to 3.5 years in Peru and northern Chile. Parasites of $E$. analoga include larval forms of the acanthocephalan Profilicollis altmani, the digenean Maritrema sp., the eucestodes Nybelinia sp. and Eutetrarhynchus sp., the nematodes Proleptus sp. and Spiruroidea gen. sp. known from the Peruvian coast (Oliva et al. 1992; Alvitres et al. 1999a). Emerita analoga from northern Chile is a host for larval P. altmani and Proleptus sp. (Oliva et al. 1992), P. altmani being quantitatively the most important parasite. The life cycle of $P$. altmani was experimentally elucidated by Mateo et al. (1983). In brief, eggs are released from adult worms living in the intestine of gulls of the genus Larus (L. pipixcan, L. belcheri, L. modestus, L. serranus) and Calidris sp. (Oliva et al. 1992). Eggs are filtered by $E$. analoga and cystacanths develop and encyst in the crab coelomic cavity. The cycle is completed when an infected mole crab is ingested by a marine bird and the cystacanth develops to the adult stage. The cystacanth of $P$. altmani like other members of Profilicollis is long-lived and probably remains infective throughout the life of the mole crab (Thompson 1985).

In this paper we evaluate the quantitative characteristics of the infection of $P$. altmani in E. analoga in order to evaluate the potential impact of EN on parasite burden. Specifically, we are discussing whether changes in quantitative characteristic of parasite infection are a direct consequence of EN or a cascade effect.

\section{Methods}

We collected a total of 1,279 specimens of the mole crab E. analoga from Mejillones beach, northern Chile $\left(23^{\circ} 01^{\prime} \mathrm{S}\right.$ $70^{\circ} 30^{\prime} \mathrm{W}$, Fig. 1). Samples were taken along three transects at equally intercepted stations with a core $(15 \mathrm{~cm}$ in diameter) in March 1998 (EN year, $n=604$ ) and March 2002 (non-EN year, $n=675$ ). Sediment was sieved $(1 \mathrm{~mm}$ mesh) and all specimens of $E$. analoga frozen $\left(-18^{\circ} \mathrm{C}\right)$ until examination. After thawing, cephalothorax length (considered as standard size) was measured $(0.1 \mathrm{~mm}$ precision $)$ and specimens were dissected. We searched specifically for larval acanthocephalans in the coelomic cavity of the mole crabs. For each crab we quantified the infrapopulation of $P$. altmani as defined by Bush et al. (1997) (number of a given parasite species in one host). Because preliminary analyses showed that prevalence of infection (as defined by Bush et al. 1997) was significantly correlated with mean size of the host for the EN year, but not for the non-EN year, we defined four arbitrary size classes, in order to evaluate the significance of the observed differences in mean intensity and prevalence of infection for each size class. The significance of the difference in mean intensity between years was tested with an ANOVA following $\log (n+1)$ transformation of the data, whereas a potential difference in prevalence of infection was tested using the Chi-square test (Yates correction). Statistical analyses followed Zar (1996).
Fig. 1 Position of the sampling location (black rectangle) in Bahía de Mejillones, northern Chile

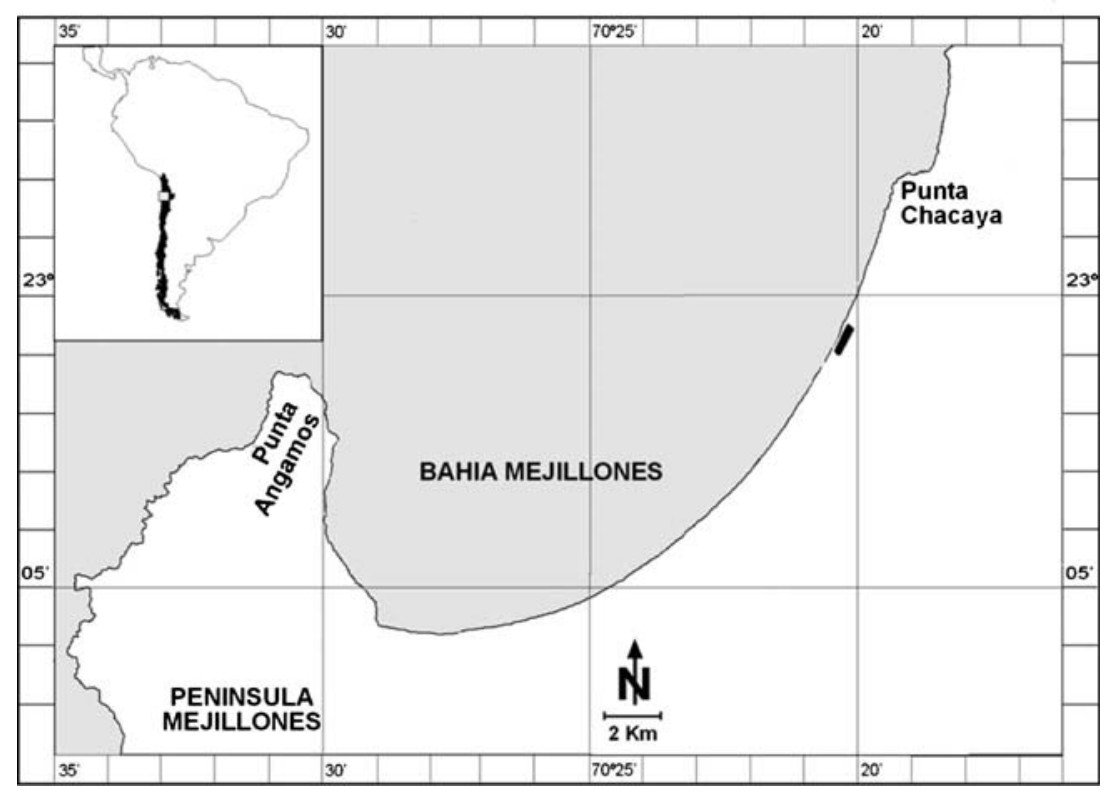




\section{Results}

The size of mole crabs for the EN year ranged from 3.1 to $35.5 \mathrm{~mm}($ mean $=19 \mathrm{~mm}, \mathrm{SD}=6.8)$ and for the non-EN year, from 3.1 to $34.5 \mathrm{~m}$ (mean $=19.2 \mathrm{~mm}, \mathrm{SD}=6.5)$. Mean sizes between years do not differ significantly $\left(F_{1,1277}=0.473, P=0.49\right)$. The size distribution of mole crabs follows the same trend for EN and non-EN years as shown in Fig. 2. Table 1 shows sample size, mean size for each size class, $F$ value and probability. Both mean intensity and prevalence of infection of $P$. altmani differ significantly for the whole sample (Prevalence: $\chi^{2}=27.09$, $P<0.001$; mean intensity: $\left.F_{1,1131}=40.67, P<0.001\right)$ and for each size class between EN and non-EN years. Higher values occur in non-EN years, as shown in Tables 2 and 3. Prevalence reached $100 \%$ for the larger size classes both in EN and non-EN years.

\section{Discussion}

The coastal zone of the Humboldt Current upwelling system is significantly influenced by the ENSO. Both its warm (El Niño: EN) and cold (La Niña: LN) phase have drastic implications for the ecology, socio-economy and infrastructure. ENSO is not only involving the tropical marine realm, but also the global atmosphere. It comprises an unstable interaction between the sea surface temperature (SST) and the atmospheric pressure and results in altered winds, rainfall, thermocline depth, and circulation patterns, strongly impacting the biological productivity, feeding and
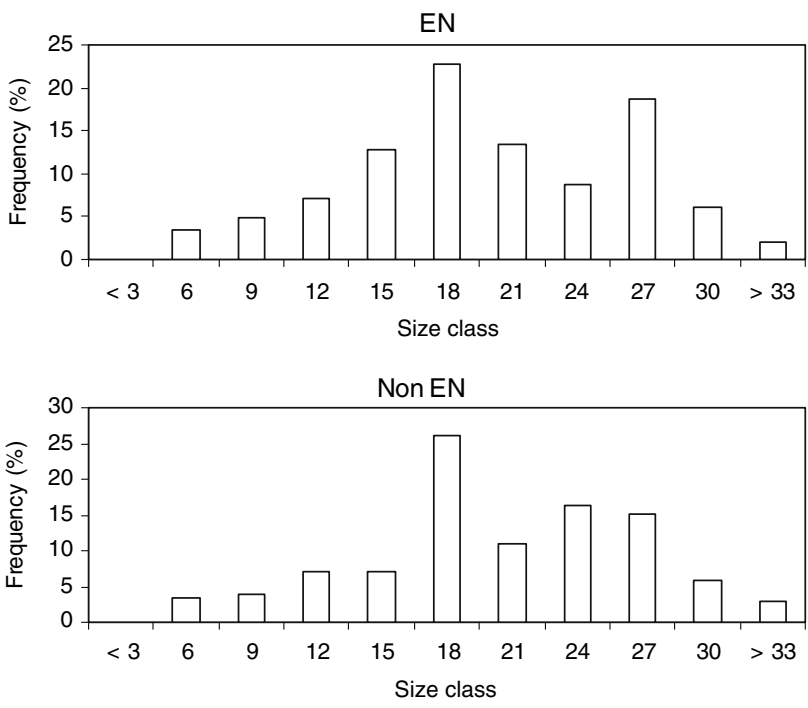

Fig. 2 Size structure (size classes of $3 \mathrm{~mm}$ intervals) of mole crabs (Emerita analoga) during EN and non-EN conditions in Bahía de Mejillones, northern Chile
Table 1 Emerita analoga in northern Chile

\begin{tabular}{|c|c|c|c|c|c|}
\hline Size class $(\mathrm{mm})$ & EN & Non-EN & $F$ & $d f$ & $P$ \\
\hline$<8$ & $5.8(38)$ & $5.8(40)$ & 0.00 & 1,76 & 0.99 \\
\hline$>8-18$ & $14.6(262)$ & $14.8(280)$ & 0.829 & 1,540 & 0.36 \\
\hline$>18-28$ & $23.2(257)$ & $23.2(305)$ & 0.0 & 1,560 & 0.98 \\
\hline$>28$ & $31.3(47)$ & $30.9(50)$ & 0.5 & 1,95 & 0.48 \\
\hline
\end{tabular}

Mean size of the four size classes defined during EN and non-EN conditions (sample size for each range size in parenthesis), $F$ value (ANOVA), degree of freedom $(d f)$ and probability $(P)$

Table 2 Mean intensity (SD in parenthesis) of Profilicollis altmani parasitizing E. analoga during EN and non-EN conditions

\begin{tabular}{|c|c|c|c|c|c|}
\hline \multirow[t]{2}{*}{ Size class $(\mathrm{mm})$} & EN & Non-EN & $F$ & $d f$ & $P$ \\
\hline & \multicolumn{5}{|c|}{ Mean intensity } \\
\hline$<8$ & $1.5(0.80)$ & $2.3(1.08)$ & 11.8 & 1,57 & $<0.00$ \\
\hline$>8-18$ & $3.3(2.17)$ & $4.2(2.41)$ & 20.3 & 1,484 & $<0.00$ \\
\hline$>18-28$ & $4.2(2.97)$ & $5.3(3.41)$ & 18.0 & 1,489 & $<0.00$ \\
\hline$>28$ & $5.5(2.78)$ & $7.1(3.07)$ & 7.69 & 1,95 & 0.007 \\
\hline
\end{tabular}

$F$ value (ANOVA), degree of freedom $(d f)$ and probability $(P)$

reproduction of fish, birds and marine mammals (Fiedler 2002) as well as the structure of benthic communities (Rojo et al. 2002; Escribano et al. 2004).

The impact of the last EN (1997-1998) in South America has been well documented (e.g., Peña et al. 2005; Riascos 2006). Mouritsen and Poulin (2002) emphasized that, despite the evidence that parasites can influence the composition and structure of natural communities, parasite transmission is often strongly affected by weather conditions. In the last review of the NAO (Ottersen et al. 2001), the mirror phenomena of EN in the northern hemisphere, parasite-host interactions were not considered at all. A similar picture was evident in the last review of EN impacts in the upwelling zone of the Humboldt Current System (Escribano et al. 2004). Examples of EN-mediated parasite

Table 3 Profilicollis altmani in E. analoga. Prevalence of infection during EN and non-EN conditions

\begin{tabular}{|c|c|c|c|c|}
\hline Size class $(\mathrm{mm})$ & \multicolumn{3}{|c|}{ Prevalence } & $P$ \\
\hline$<8$ & 57.9 & 92.5 & 10.85 & $<0.001$ \\
\hline$>8-18$ & 83.6 & 95.4 & 19.98 & $<0.001$ \\
\hline$>18-28$ & 84.4 & 89.8 & 3.21 & 0.07 \\
\hline$>28$ & 100 & 100 & NA & \\
\hline
\end{tabular}

NA not applicable

Corrected Chi-square $\left(\chi_{\text {cor }}^{2}\right)$ and probability $(P)$ 
Fig. 3 Diagram showing the life cycle of $P$. altmani during EN and non-EN conditions. 1 Adult $P$. altmani in host (marine birds) intestine. 2 Eggs released to the environment with host's faeces and filtered by $E$. analoga. 3 Cystacanth of $P$. altmani in the coelomic cavity of the mole crab. 4 Mole crabs are eating by marine birds that become infected with cystacanth that develop into adult in the host's intestine

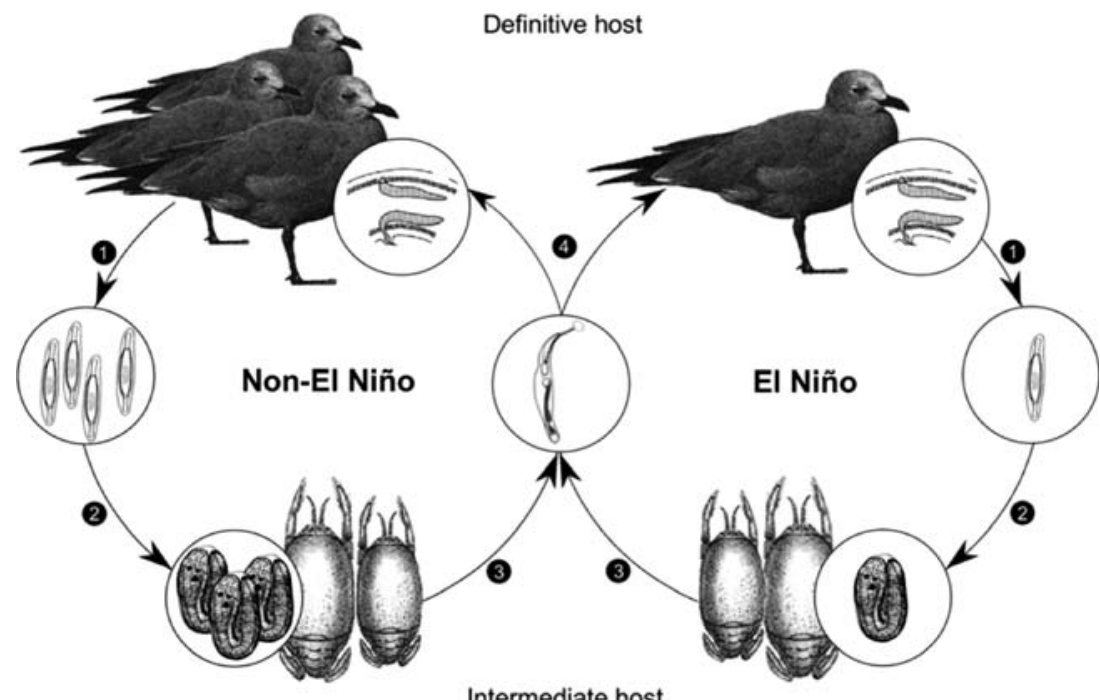

Intermediate host induced host dynamics do however exist: Mouritsen and Poulin (2002) gave a comprehensive list of articles that directly or indirectly showed that parasite-induced host population dynamics or distributions are governed by short-term changes in weather conditions or general climate change. Recently, Mouritsen et al. (2005) demonstrated by evaluating a theoretical model and field data that an increase in water temperature of $3.8^{\circ} \mathrm{C}$ will likely result in a parasite-induced collapse of an amphipod population. Almost all of the cited articles are related to temperaturedependent effects on emergence and survival of larval stages, egg and larval development, infectivity, and parasite survival in helminths (Monogenea, Digenea, Cestoda, Nematoda). In addition, indirect cascade effects are included and emphasized in relation to the impact of parasites and climate changes on host population and community structure, but the impact of population changes in intermediate and/or definitive hosts of the parasite population remains unclear.

Alvitres et al. (1999a) described changes in the prevalence of infection of larval helminths in the mole crab E. analoga from Lambayeque, northern Peru $\left(6^{\circ} 44^{\prime} \mathrm{S}\right.$ $79^{\circ} 47^{\prime} \mathrm{W}$ ) before and during EN 1997-1998. Overall, $84.5 \%$ of the samples taken prior to EN and $79 \%$ of the samples taken during EN were parasitized with one or more specimens of seven helminths species. A Chi-square test, carried out from their Table 1 demonstrates significant differences $\left(\chi^{2}=6.34, P=0.012\right)$, suggesting that mole crabs were more parasitized before EN than during ENSO. Alvitres et al. (1999a) also indicated that the most important parasite infestation (higher prevalence) was due to Polymorphus bullocki (=Profilicollis altmani, see Tantalean and Cardenas 2004) and that changes in global prevalence were mainly due to differences in prevalence of infection of the cestode Eutetrarhynchus sp. and the nematode Proleptus sp. and an unidentified Spiruroidea. In contrast, the prevalence of $P$. altmani was significantly higher before EN evident from a Chi-square test $\left(\chi^{2}=26.6, P<0.001\right)$ carried out from Table 2 of Alvitres et al. (1999a). Thus, the revised analyses of their data taken before and during EN are in line with our data (during and after EN). However, it has to be noted that this re-analysis of published data has to be considered with caution, because the sample sizes indicated in Tables 1 and 2 of the former study are not congruent. Additionally, and as already indicated by Contreras et al. (2000), E. analoga lives up to 3.5 years in northern Chile. Furthermore, samples (at least those of large size $=$ older) taken during $\mathrm{EN}$ were exposed to the infective stage (eggs) before EN. This is important to consider, because $P$. altmani is found encysted in the coelomic cavity of $E$. analoga where it accumulates like other encysted larval forms over time, remaining alive throughout the life of the host (Thompson 1985). Our non-EN samples were taken 4 years after EN. We are thus convinced that many specimens sampled during nonEN conditions recruited into the adult mole crab population after EN and were thus not affected by this warm water event. In addition, quantitative characteristic of the infection shows higher values of prevalence and mean intensity in the older cohorts, suggesting absence of parasite induced mortality of the host (Latham and Poulin 2002). Because perturbations in ecosystems affecting the food web structure will also impact parasite transmission, and thus modify parasite abundance (Marcogliese 2005), we have to look at the two components of the food web associated with $P$. altmani in order to detect potential changes that can help us to understand the observed differences. These are the mole crabs and their predator birds (littoral fishes, both teleost and elasmobranchs, also 
prey on E. analoga, but they do not play any role in the life cycle of $P$. altmani). Although the effect of EN on the population biology of $E$. analoga has been described (Alvitres et al. 1999b), our results did not detect changes at the population level. The availability of mole crabs (measured as catches per sampling effort) was almost the same in either situation, EN and non-EN years. Moreover, the size distribution was not affected (Fig. 2). By contrast, predators such as sea birds (i.e., Larus spp. and Calidris sp.) are strongly affected during EN, breeding may fail up to $100 \%$ in L. modestus from Northern Chile (Guerra et al. 1988) and adult survival is severely impaired in north Atlantic bird species (Sandvik 2004). According to Luna-Jorquera et al. (2003) a common pattern among species with rapid recoveries after EN are large clutch sizes, high growth rates, and early reproductive ages. Seabird assemblages along the Humboldt Current System are dominated by species with these characteristics, like Larus spp. Latham and Poulin (2003) suggested that there is weak evidence that infection levels by the related $P$. novaezelandensis in shore crabs are related to the distribution and abundance of shore bird hosts both in a temporal and spatial scale. Our results show that the negative impact of EN on the abundance of the definitive host for $P$. altmani could explain changes in the abundance of the parasite (Fig. 3). Depleted bird populations represent a loss of definitive hosts for $P$. altmani, yielding in a decreased source for $P$. altmani eggs, the infective stage of E. analoga (Fig. 3). As the mole crab is not able to actively avoid the infection, ENinduced critical physiological conditions are not reflected in higher infection rates, as expected for those host species with an altered physiological condition. For this reason, changes in the parasite population do not represent a direct consequence of EN but the last step of a "cascade effect" starting with the EN reducing the abundance of marine birds that act as definitive hosts for P. altmani.

Acknowledgments We thank Robert Poulin (Otago University, New Zealand) for comments on the manuscript and Julie Cunningham for her correction of the English. CENSOR is financed through the INCO-DEV-FP6 programme and supported by the European Commission (contract no. 511071). Partial support came from PBCTCONICYT (Chile) grant CENSOR-RUE02 and Cooperative Program between the Alfred Wegener Institute for Polar and Marine Research and the Instituto de Investigaciones Oceanológicas, Universidad de Antofagasta, Chile. This is CENSOR publication no. 84 .

\section{References}

Alvitres V, Chanamé J, Fupuy J, Chambergo A, Cortez M (1999a) Cambios en la prevalencia de helmintos parásitos de Emerita analoga por efecto de "El Niño" 1997-1998. Rev Peru Biol Vol extraord, p 69-76
Alvitres V, Chanamé J, Fupuy J, Chambergo A, Angulo E, Amaya R, Cortez M (1999b) Influencia de "El Niño" 1997-1998 sobre la fecundidad de Emerita analoga en Lambayeque-Perú. Rev Peru Biol, Vol extraord, p 77-84

Alvitres V, Fupuy J, Chanamé J, Chambergo A, Cortez M (2002) Effects of La Niña 98-2000 on the population structure of Emerita analoga, Lambayeque, Perú. In: Salinas S et al (eds) Impacts of El Niño and basin-scale climate change on ecosystems and living resources: a comparison between the California and the Humboldt Current System. Invest Mar Valparaíso 30:130-131

Arntz W (2002) The role of El Niño, La Niña and climate change in the Pacific eastern boundary currents: an integrated introductory view. In: Salinas $S$ et al (eds) Impacts of El Niño and basin-scale climate change on ecosystems and living resources: a comparison between the California and the Humboldt Current System. Invest Mar. Valparaíso 30:81-82

Arntz W, Gallardo VA, Gutierrez D, Isla E, Levin LA, Mendo J, Neira C, Rowe GT, Tarazona J, Wolff M (2006) El Niño and similar perturbatin effects on the benthos of the Humboldt, California, and Benguela Curent upwelling ecosystems. ADGEO 6:243-265

Bush AO, Lafferty KD, Lotz JM, Shostak AW (1997) Parasitology meets ecology on its own terms: Margolis et al. revisited. J Parasitol 83:575-583

Contreras H, Jaramillo E, Quijon P (2000) Natural history of Emerita analoga (Stimpson) (Anomura, Hippidae) in a sandy beach of northern Chile. Rev Chil Hist Nat 73:705-715

Escribano R, Daneri G, Farías L, Gallardo VA, González HE, Gutierrez D, Lange CB, Morales CE, Pizarro O, Ulloa O, Braun M (2004) Biological and chemical consequences of the 19971998 El Niño in the Chilean coastal upwelling system: a synthesis. Deep Sea Res II 51(20-21):2389-2411

Fiedler PC (2002) Environmental change in the eastern tropical Pacific Ocean: review of ENSO and decadal variability. Mar Ecol Prog Ser 244:265-283

Guerra CG, Fitzpatrick LC, Aguilar RE, Venables BJ (1988) Reproductive consequence of El Niño Southern oscillation in gray gull Larus modestus. Colonial Waterbird 11:170-175

Hudson P, Greenman J (1998) Competition mediated by parasites: biological and theoretical progress. Trends Ecol Evol 13:387390

Koepcke HW, Koepcke M (1952) Sobre el proceso de transformación de la materia orgánica en playas arenosas del Peru. Publ Mus Nac Hist Nat "Javier Prado" Ser A (8):1-25

Lafferty KD, Kuris AM (1999) How environmental stress affects the impacts of parasites. Limnol Oceanogr 44(3 part 2):925-931

Latham ADM, Poulin R (2002) Field evidence of the impact of two acanthocephalan parasites on the mortality of three species of New Zealand shore crabs (Brachyura). Mar Biol 141:1131-1139

Latham ADM, Poulin R (2003) Spatiotemporal heterogeneity in recruitment of larval parasites to shore crab intermediate host: the influence of shore bird definitive hosts. Can J Zool 81:12821291

Luna-Jorquera G, Simenone A, Aguilar R (2003) Ecofisiología de animales endotermos en un desierto cálido y un mar frío: el caso de las aves marinas de la corriente de Humboldt. In: Bozinovic F (ed) Fisiología ecológica y evolutiva. Ediciones Univ. Católica de Chile, Santiago, pp 341-368

Marcogliese D (2005) Parasites of the superorganism: are they indicators of ecosystem health? Int J Parasitol 35:705-716

Mateo E, Córdova R, Guzmán E (1983) Polymorphus (Profilicollis) bullocki, acantocéfalo de la gaviota Larus belcheri. Contribución al conocimiento de su ciclo biológico. Bol Lima 5:67-71

Minchella DJ, Scott ME (1991) Parasitism: a cryptic determinant of animal community structure. Trends Ecol Evol 6:250-254 
Mouritsen KN, Poulin R (2002) Parasitism, climate oscillations and the structure of natural communities. Oikos 97:462-468

Mouritsen KN, Tompkins D, Poulin R (2005) Climate warming may cause a parasite-induced collapse in coastal amphipod populations. Oecologia 146:476-483

Oliva ME, Luque JL, Cevallos A (1992) Parásitos de Emerita analoga (Stimpson) (Crustacea): implicancias ecológicas. Bol de Lima 14:77-80

Osorio C, Bahamonde N (1967) El "Limanche" Emerita analoga (Stimpson) en Chile (Crustacea, Decapoda, Anomura) Bol Mus Nac Hist Nat Chile 24(5):61-116

Ottersen G, Planque B, Belgrano A, Prost E, Reid PC, Stenseth NC (2001) Ecological effects of the North Atlantic Oscillation. Oecologia 128:1-14

Peña TS, Johst K, Grimm V, Arntz W, Tarazona J (2005) Population dynamics of a polychaete during three El Niño events: disentangling biotic and abiotic factors. Oikos 111:253-258

Poulin R (2006) Global warming and temperature-mediated increases in cercarial emergence in trematode parasites. Parasitol 132:143151

Poulin R, Mouritsen KN (2006) Climate change, parasitism and the structure of intertidal ecosystems. J Helminthol 80:183-191
Riascos JM (2006) Effects of El Niño-Southern oscillation on the population dynamics of the tropical bivalve Donax dentifer from Málaga bay. Colomb Pac Mar Biol 148:1283-1293

Rojo M., Oliva ME, Villalobos C (2002) Long term effects of "El Niño" on the structure of soft-bottom macrozoobenthos communities in northern Chile. In: Salinas S et al (eds) Impacts of El Niño and Basin-scale climate change on ecosystems and living resources: a comparison between the California and the Humboldt Current System. Invest Mar Valparaíso 30:157-158

Sandvik H (2004) Life-history and breeding biology of seabirds in a changing environment: a comparative approach. Dr.scient. thesis, Universitetet i Troms $\varnothing$, Troms $\varnothing$, Norway $42 \mathrm{pp}$

Tantalean M, Cardenas J (2004) Consideraciones sobre Profilicollis altmani (Perry, 1942) Van Cleave, 1947 en el Perú. Rev Peru Biol 11:109-111

Thompson AB (1985) Analysis of Profilicollis botulus (Acanthocephala: Echinorhynchidae) burdens in the shore crab Carcinus maenas. J Anim Ecol 54:595-604

Windsor DA (1998) Most of the species on Earth are parasites. Int J Parasitol 28:1939-1941

Zar JH (1996) Biostatistical analysis, 3rd edn. Prentice Hall, Upper Saddle River, $662 \mathrm{p}$ 